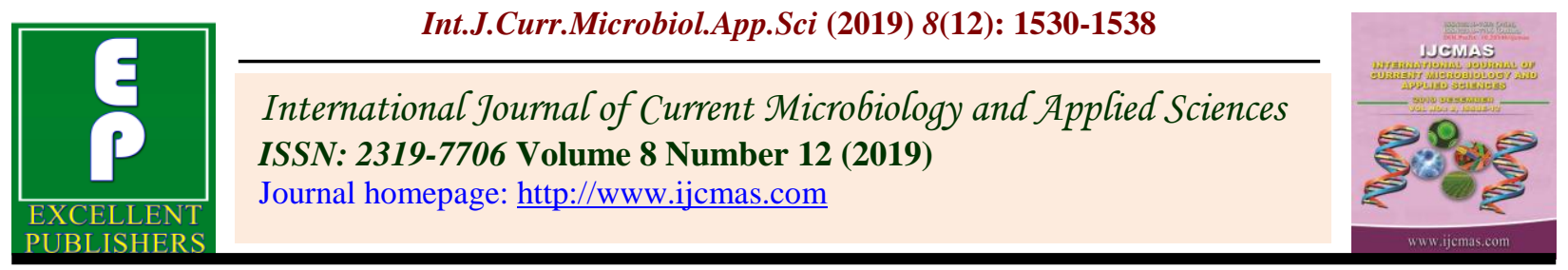

Original Research Article

https://doi.org/10.20546/ijcmas.2019.812.183

\title{
Effect of Different Levels of Nutrients and Dates of Sowing on Growth and Yield of Maize Crop (Zea mays L.)
}

\author{
Shalu Shyoran*, Ram Bharose and Rajveer \\ Department of Environmental Science, School of Forestry and Environment, Sam \\ Higginbottom Institute of Agriculture, Technology and Sciences ((Formerly Allahabad \\ Agricultural Institute)), Allahabad-211007, U. P., India \\ *Corresponding author
}

\section{A B S T R A C T}

\begin{tabular}{|l|}
\hline K e y w o r d s \\
$\begin{array}{l}\text { Different levels of } \\
\text { nutrients, Dates of } \\
\text { sowing, Maize, Zea } \\
\text { mays L }\end{array}$ \\
\hline Article Info \\
\hline $\begin{array}{l}\text { Accepted: } \\
\text { 12 November } 2019 \\
\text { Available Online: } \\
\text { 10 December } 2019\end{array}$ \\
\hline
\end{tabular}

\section{Introduction}

Maize (Zea mays L.) is an annual plant which belongs to family Gramineae. Maize is an important cereal of crop of world which is grown under diverse climatic conditions. Maize occupies a pride place among cereal crops in India and due to its high yield potential called the queen of cereals
A field experiment was conducted during Kharif season, 2015 at the Crop Research Farm, School of Forestry \& Environment, SHIATS, Allahabad (U.P.) to find out the effect of different levels of nutrients and dates of sowing on growth and yield of maize (Zea mays L.) under Allahabad climatic condition. The experiment was lay out in factorial $(3 \times 4)$ Randomized Block Design with twelve treatments, replicated thrice. The results on to the different parameters was found significant, showed under treatment $\mathrm{T}_{3}$ (10 July sowing date $+135 \mathrm{~kg}$ nitrogen, $90 \mathrm{~kg}$ phosphorus, $45 \mathrm{~kg}$ potash). The maximum plant height $(212.56 \mathrm{~cm})$, number of cob plant ${ }^{-1}(2.00)$, cob length $(25.66 \mathrm{~cm})$, cob girth $(12.66 \mathrm{~cm})$, weight of grains $\mathrm{cob}^{-1}(82.10 \mathrm{~g})$, number of grains row $\operatorname{cob}^{-1}(14.03)$, number of grains $\operatorname{cob}^{-1}(395.26)$, dry weight plant ${ }^{-1}(157.36 \mathrm{~g})$ was recorded in treatment $\mathrm{T}_{3}$ [10 July DOS + $135 \mathrm{~kg}$ nitrogen ha ${ }^{-1}, 90 \mathrm{~kg}$ phosphours $\mathrm{ha}^{-1}$ and $45 \mathrm{~kg}$ potash ha ${ }^{-1}$ ] (10 July DOS $+150 \%$ NPK of Recomnded dose of fertilizer). The similar effect was also recorded in the yield and Yield attributes. Treatment $\mathrm{T}_{3}$ (DOS $10 \mathrm{July}+$ nitrogen $135 \mathrm{~kg}$,phosphorus $90 \mathrm{~kg}$, potash $\left.45 \mathrm{~kg} \mathrm{ha}^{-1}\right)$ produced the maximum seed yield $\left(57.33 \mathrm{q} \mathrm{ha}^{-1}\right)$, stover yield $(88.66 \mathrm{q}$ $\mathrm{ha}^{-1}$ ), Test weight $(222.00 \mathrm{~g})$, Harvest index $(39.26 \%)$. Treatment $\mathrm{T}_{3}$ (DOS $10 \mathrm{July}+$ nitrogen $135 \mathrm{~kg}$, phosphorus $90 \mathrm{~kg}$, potash $45 \mathrm{~kg} \mathrm{ha}^{-1}$ ) also recorded the highest gross return (97481 $\left.\mathrm{Rs} \mathrm{ha}^{-1}\right)$, net return (61216.88 $\mathrm{Rs} \mathrm{ha}^{-1}$ ) and benefit cost ratio (1.68). 
sweeteners, cosmetics, more recently as biofuel etc. (Govt. of India). No other cereal is being used in as many ways as maize. Maize grain has elevated nutritive value as it contains about $72 \%$ starch, $10 \%$ protein, $4.8 \%$ oil, $5.8 \%$ fiber and 3\% sugar (Rafiq et al., 2010). Maize is grown during south west monsoon season (June-September). As the crop is predominantly grown under rain fed conditions, it is subjected to both biotic and abiotic stresses which are largely influenced by the particularly distribution and quantity of rainfall. Weather is one of the key components influencing its production and productivity. Climate variability and change have a direct, often adverse, effect on the quantity and quality of agricultural production. The climate of an area is highly correlated with its vegetation and, by extension, the type of crop that can be cultivated. Temperature, rainfall, humidity, sunshine (day length) are important climatic elements that affect crop production. The overall predictability of these climatic elements is imperative for the day-to-day and medium term planning of farm operations (Sowunmi and Kintola, 2010).

Studies indicate that weather during cropping season strongly influence the crop growth and it accounts for two- third of the variation in productivity while other factors including soil and nutrient management account for one third of the productivity (Rao et al., 1999). The predominant influence of weather is operative even before the crop is sown, as the moisture availability and the thermal regime of the seed zone determine the date of sowing and the appropriate cultivar to be sown. In spite of cultivation of high yielding varieties, improved cultural practices and plant protection measures, favorable weather is a must for good harvests (Rao et al., 1999).

There are several evidences showing that, delay in sowing of maize beyond July results in yield reduction. In the event of late onset of monsoon rains and erratic rainfall farmers are forced to take- up sowing late $i$. $e$., beyond July 15 and the sowing may even be extended to the end of August month. Shift in sowing dates directly influence both thermo and photoperiod and consequently a great bearing on the phasic development and partitioning of dry matter. Quantification of these effects may help in the choice of sowing time and match phenology of crop in specific environment to achieve higher grain yield. Hence, there is a need to study the influence of different weather parameters on the performance of maize grown different environments as affected by change in sowing date (Leelarani et al., 2013).

\section{Materials and Methods}

The experiment was carried out during Kharif season 2015 at Crop Research Farm, Department of Environmental Science, School of Forestry and Environment, Sam Higginbottom Institute of Agriculture, Technology and Sciences, Allahabad (U.P.), which is located at $25^{\circ} 24^{\prime} 42^{\prime \prime} \mathrm{N}$ latitude, $81^{0}$ 50' 56" E longitude and $98 \mathrm{~m}$ altitude above the mean sea level. This area is situated on the right side of the river Yamuna by the side of Allahabad Rewa Road about $5 \mathrm{~km}$ away from Allahabad city. It consists of three sowing date 10 July, 20 July, 30 July and four levels of nutrients(NPK) control, $50 \%$ NPK of R.D.F, $100 \%$ NPK of R.D.F.,150 \%NPK of R.D.F. The soil was sandy loam in texture, the $\mathrm{pH}$ of the soil was slightly alkaline in reaction (7.4), it was low in organic carbon $(0.30 \%)$, low in available nitrogen content $(187.3 \mathrm{~kg}$ ha $\left.{ }^{1}\right)$, medium in available phosphorus $(34.5 \mathrm{~kg}$ $\left.\mathrm{ha}^{-1}\right)$, low in available potassium $\left(87.1 \mathrm{~kg} \mathrm{ha}^{-1}\right)$ and low in available sulphur (5 ppm) contents. The dose of nutrients(NPK) in the form of UREA,DAP and muriate of potash was applied at Nitrogen $45 \mathrm{~kg} \mathrm{ha}^{-1}, 90 \mathrm{~kg} \mathrm{ha}^{-1}, 135$ $\mathrm{kg} \mathrm{ha}^{-1}$ and Phosphurs $30 \mathrm{~kg} \mathrm{ha}^{-1}, 60 \mathrm{~kg} \mathrm{ha}^{-1}$, $90 \mathrm{~kg} \mathrm{ha}^{-1}$ and Potash $15 \mathrm{~kg} \mathrm{ha}^{-1} 30 \mathrm{~kg} \mathrm{ha}^{-1} 45$ 
$\mathrm{kg} \mathrm{ha}{ }^{-1}$ at the time of sowing as per the treatments. Treatments were $\left.\mathrm{T}_{0}-\left(\mathrm{D}_{1}+\mathrm{Nu}\right)\right) @$ 10 July DOS+Control nutrients(NPK), $\mathrm{T}_{1}$ $\left(\mathrm{D}_{1}+\mathrm{Nu} 1\right) @ 10$ July DOS $+50 \%$ nutrients (NPK) of $50 \%$ R.D.F ha ${ }^{-1}, \mathrm{~T}_{2}-\left(\mathrm{D}_{1}+\mathrm{Nu} 2\right)$ @ 10July DOS $+100 \%$ Nutrients of R.D.F ha ${ }^{-1}$, $\mathrm{T}_{3}-\left(\mathrm{D}_{1}+\mathrm{Nu} 3\right) @ 10 \mathrm{July} \mathrm{DOS}+150 \%$ Nutrients of R.D.F ha ${ }^{-1}, \mathrm{~T}_{4}-\left(\mathrm{D}_{2}+\mathrm{Nu}\right)$ @ 20July DOS+Control nutrients (NPK), $\mathrm{T}_{5^{-}}$ $\left(\mathrm{D}_{2}+\mathrm{Nu} 1\right) @ 20 J u l y$ DOS $+50 \%$ nutrients (NPK) of $50 \%$ R.D.F ha ${ }^{-1,} \mathrm{~T}_{6}-\left(\mathrm{D}_{2}+\mathrm{Nu} 2\right)$ @ 20JulyDOS $+100 \%$ Nutrients of R.D.F ha ${ }^{-1}, \mathrm{~T}_{7}$ - $\left(\mathrm{D}_{2}+\mathrm{Nu} 3\right) @$ 20July DOS + 150\% Nutrients of R.D.F ha ${ }^{-1}, \quad \mathrm{~T}_{8}-\left(\mathrm{D}_{3}+\mathrm{Nu} 0\right)$ @30July DOS+Control nutrients (NPK), $\mathrm{T}_{9}-\left(\mathrm{D}_{1}+\mathrm{Nu} 1\right)$ @ 30 July DOS $+50 \%$ nutrients (NPK) of 50\%R.D.Fha ${ }^{-1}, \mathrm{~T}_{10}-\left(\mathrm{D}_{3}+\mathrm{Nu} 2\right)$ @ 30 July DOS $+100 \%$ Nutrients of R.D.F ha ${ }^{-1}, \mathrm{~T}_{11}-\left(\mathrm{D}_{3}+\right.$ Nu3) @ 30July DOS + 150\% Nutrients of R.D.F ha ${ }^{-1}$. (R.D.F = Recommended dose of fertilizer).

\section{Results and Discussion}

Interaction effect of nutrients (NPK) Level and sowing date on growth parameter on maize

The interaction effects of different levels of Nutrients(NPK) and dates of sowing on plant height at 25 DAS was found non- significant and at 50 DAS was found significant and The effect of different levels of nutrients on plant height at 25 and 50 DAS was found significant sowing date on plant height was nonsignificant. The interaction effect of different levels of nutrients and dates of sowing on plant height at 25 DAS and 50 DAS was found non significant. The maximum plant height recorded at 25, 50, 75 DAS was 30.66 (T9-30July sowing date $+150 \%$ of N.P.K of R.D.F ha ${ }^{-1)}, 160.30,201.53 \mathrm{~cm}$ respectively in $\mathrm{T}_{3}$-10July sowing date $+150 \%$ of N.P.K of R.D.F ha ${ }^{-1}$ ). Similar results have also been recorded by Awasthi et al., (2009) reported that crops sown on June 30, regardless of cultivar, gave the highest Plant height as compare to July 10 and July 20 sown crops.

The interaction effect of deferent levels of nutrients and dates of sowing on dry weight of plant $^{-1}$ was also found significant, the maximum dry weight $157.36 \mathrm{~g}$ was found in treatment combination $\mathrm{D}_{1}+\mathrm{Nu}_{3}$ On 75 DAS respectively in $\mathrm{T}_{3}-10$ July sowing date $+150 \%$ of N.P.K of R.D.F ha ${ }^{-1}$.).

Similar results have also been recorded Kumar (2009), reported that application of $120 \mathrm{~kg} \mathrm{~N}$ $\mathrm{ha}^{-1}$ significantly increased the plant height and dry matter of sweet corn over $80,40 \mathrm{~kg} \mathrm{~N}$ $\mathrm{ha}^{-1}$ and control for two successive years.

The interaction effects of different levels of Nutrients (NPK) and date of sowing on number of cob plant ${ }^{-1}$ was also found non significant, the maximum number of cob plant $^{-1} \quad 2.00$ was found in treatment combination $\mathrm{D}_{1}+\mathrm{Nu}_{3}$ respectively in $\left(\mathrm{T}_{3}\right.$ 10July sowing date $+150 \%$ OF N.P.K of R.D.F $\mathrm{ha}^{-1}$ ) on harvesting stage. Similar results have also been recorded by Awasthi et al., (2009) reported that crops sown on June 30 , regardless of cultivar, gave the highest harvest index, net returns and benefit: cost ratio, plant height, shoot girth, cob plant ${ }^{-1}$, cob weight, cob length, grains $\operatorname{cob}^{-1}$, grains weight $\mathrm{cob}^{-1}, 1000$ - grain weight, grain yield and stover yield as compare to July 10 and July 20 sown crops.

Interaction effect of different levels nutrients (NPK) and sowing date on yields attributes and yield of maize

The interaction effects of different levels of nutrients (NPK) and sowing date on grains $\mathrm{cob}^{-1}$, grain yield $\mathrm{cob}^{-1}(\mathrm{~g})$, and test weight significant. The highest number grains $\mathrm{cob}^{-1}$, grain yield $\mathrm{cob}^{-1}$, and test weight recorded $395.26,82.40 \mathrm{~g}, 222.00 \mathrm{~g}$ respectively in was found in treatment combination $\mathrm{D}_{1}+\mathrm{Nu}_{3}$ 
respectively in $\left(\mathrm{T}_{3}\right.$-10July sowing date + $150 \%$ OF N.P.K of R.D.F ha ${ }^{-1}$ ) Similar results have also been recorded by Parashar, (2011) At Udaipur (Raj.), maize sown on June 1st recorded highest cob, number of grains $\mathrm{cob}^{-}$ ${ }^{1}$,number of plant, test weight, weight of grains $\operatorname{cob}^{-1}$ and grain yield over early (June 20) and late sowing (July 11) (APR, 2012).

The interaction effect of different levels of nutrients and dates of sowing on number of grains $\operatorname{cob}^{-1}$ was also found significant, the maximum number of grains $\mathrm{cob}^{-1} 395.26$ was found in treatment combination $\mathrm{D}_{1}+\mathrm{Nu}_{3}$.

The highest grain yield $\left(\mathrm{q} \mathrm{ha} \mathrm{h}^{-1}\right)$, Stover yield (q ha ${ }^{-1}$ ), Biological yield ( $\mathrm{q} \mathrm{ha}{ }^{-1}$ ) and harvest index $(\%)$ recorded 57.33,88.66,146,39.26in treatment combination $\mathrm{D}_{1}+\mathrm{Nu}_{3}$ respectively in $\left(\mathrm{T}_{3}\right.$-10July sowing date $+150 \%$ OF N.P.K of R.D.F ha ${ }^{-1}$ ).

Similar results have also been recorded by Awasthi et al.,(2009) reported that crops sown on June 30, regardless of cultivar, gave the highest harvest index, water use efficiency, net returns and benefit: cost ratio, plant height, shoot girth, cob plant ${ }^{-1}$,cob weight, cob length, grains $\mathrm{cob}^{-1}$, grains weight $\mathrm{cob}^{-1}, 1000$ - grain weight, grain yield and stover yield as compare to July 10 and July 20 sown crops.

Effect of different levels of nutrients and sowing dates on Agrometerological indices

\section{Growing degree day $\left(\operatorname{GDD}^{0} \mathrm{C}\right)$}

The effect of dates of sowing on GDD on flowering and Tasseling stage found significant, the maximum GDD $886.75{ }^{\circ} \mathrm{C}$, $1311.08{ }^{\circ} \mathrm{C}$ was recorded in $\mathrm{D}_{3}$ and minimum $839.08{ }^{0} \mathrm{C}, 1182.58{ }^{\circ} \mathrm{C}$ was found in.

The effect of different levels of nutrients on GDD was found significant, the maximum GDD 903.11 ${ }^{0} \mathrm{C}$, was found in $\mathrm{Nu}_{3}$ and at
Tasseling stage thr maximum GDD $1303.88^{\circ} \mathrm{C}$ was found in $\mathrm{Nu}_{0}$ and minimum $814.66{ }^{\circ} \mathrm{C}$ was found in $\mathrm{Nu}_{0}$, and at tasseling stage minimum $1169.88^{\circ} \mathrm{C}$ was found in $\mathrm{Nu}_{3}$.

The interaction effect of different levels of nutrients and dates of sowing on GDD on flowering stage was found non significant, the maximum GDD $933.66{ }^{0} \mathrm{C}$ was found in treatment combination $\mathrm{D}_{3}+\mathrm{Nu}_{3}$ and minimum $803.66^{\circ} \mathrm{C}$ was recorded in $\mathrm{D}_{1}+\mathrm{Nu}_{0}$. The interaction effect of different levels of nutrients and dates of sowing on GDD was also found significant at tessling stage, the maximum GDD $1366.33{ }^{0} \mathrm{C}$ was found in treatment combination $\mathrm{D}_{3}+\mathrm{Nu}_{0}$ and minimum $1121.66{ }^{0} \mathrm{C}$ was recorded in $\mathrm{D}_{1}+\mathrm{Nu}_{3}$

Similar result also recorded by Hara, (2003) At Ludhiana, the days taken for seedling emergence increased with delay in sowing dates. Days taken to attain Tesseling stage increased significantly as planting were delayed.

\section{Heat use efficiency $\left(\mathrm{kg} \mathrm{ha}^{-1} \mathrm{C}^{-1}\right.$ day $\left.^{-1}\right)$}

\section{Dry matter basis (75 DAS)}

The effect of different levels of nutrients and dates of sowing on HUE presented in table 14.

The effect of dates of sowing on HUE was found significant, the maximum HUE $9.00 \mathrm{~kg}$ $\mathrm{ha}^{-1}{ }^{0} \mathrm{C}^{-1}$ day ${ }^{-1}$ was recorded in $\mathrm{D}_{2}$ and minimum $8.85 \mathrm{~kg} \mathrm{ha}^{-1}{ }^{0} \mathrm{C}^{-1}$ day $^{-1}$ was found in $\mathrm{D}_{1}$ and critical difference at $5 \%$ level of significance was recorded 0.13 .

The effect of different levels of nutrients on HUE was found significant, the maximum $10.09 \mathrm{~kg} \mathrm{ha}^{-1}{ }^{0} \mathrm{C}^{-1}$ day $^{-1}$ was found in $\mathrm{Nu}_{3}$ and minimum $7.65 \mathrm{~kg} \mathrm{ha}^{-1}{ }^{0} \mathrm{C}^{-1}$ day $^{-1}$ was found in $\mathrm{Nu}_{0}$ and critical difference at $5 \%$ level of significance was recorded 0.15 . 
Table.1 Interaction table on effect of different levels of Nutrients and sowing date on growth and yield of Maize (Zea mays L.)

\begin{tabular}{|c|c|c|c|c|c|c|c|}
\hline \multirow[t]{2}{*}{ Treatment combination } & \multicolumn{3}{|c|}{ Plant height(cm) } & \multirow{2}{*}{$\begin{array}{c}\text { Plant dry } \\
\text { weight } g \\
75 \text { DAS }\end{array}$} & \multirow{2}{*}{$\begin{array}{c}\begin{array}{c}\text { Number of cob } \\
\text { plant }^{-1}\end{array} \\
\text { AT HARVEST }\end{array}$} & \multirow{2}{*}{$\begin{array}{c}\text { Number of } \\
{\text { grain } \text { cob }^{-1}}^{-1} \\
\text { AT } \\
\text { HARVST }\end{array}$} & \multirow{2}{*}{$\begin{array}{c}\text { Grain yield } \\
\text { cob }^{-1}(\mathrm{~g})\end{array}$} \\
\hline & $\begin{array}{r}25 \\
\text { DAS }\end{array}$ & 50 DAS & 75 DAS & & & & \\
\hline $\mathrm{T}_{0} \quad \mathrm{~T}_{0}$ : DOS 10 July +Control Nutrients & 14.66 & 115.56 & 156.23 & 116.16 & 1.18 & 356.00 & 64.96 \\
\hline $\begin{array}{c}\mathrm{T}_{1} \text { :DOS } 10 \text { July }+\mathrm{N} 45 \mathrm{~kg} \mathrm{ha}^{-1}, \mathrm{P} 30 \mathrm{~kg} \mathrm{ha}^{-1}, \\
\mathrm{k} 15 \mathrm{~kg} \mathrm{ha}^{-1}\end{array}$ & 33.33 & 137.23 & 182.10 & 136.43 & 1.66 & 362.33 & 69.23 \\
\hline $\begin{array}{c}\mathrm{T}_{2} \text { :DOS } 10 \text { July }+ \text { N90 } \mathrm{kg} \mathrm{ha}^{-1}, \mathrm{P} 60 \mathrm{~kg} \mathrm{ha}^{-1} \\
\mathrm{k} 30 \mathrm{~kg} \mathrm{ha}^{-1}\end{array}$ & 20.66 & 142.63 & 192.16 & 147.86 & 1.83 & 380.23 & 74.50 \\
\hline 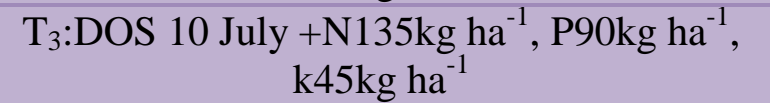 & 18.33 & 160.30 & 201.53 & 157.36 & 2.00 & 395.26 & 82.10 \\
\hline $\mathrm{T} \quad \mathrm{T}_{4}$ : DOS 20 July + control nutrients & 23.00 & 115.00 & 155.00 & 115.23 & 1.03 & 348.60 & 62.60 \\
\hline $\begin{array}{c}\text { D T:DOS } 20 \text { July + N45 kg ha }{ }^{-1}, \text { P } 30 \mathrm{~kg} \\
\text { ha }^{-1}, \mathrm{~K} 15 \mathrm{~kg} \mathrm{ha}^{-1}\end{array}$ & 30.33 & 136.20 & 180.40 & 133.10 & 1.33 & 356.20 & 66.36 \\
\hline $\begin{array}{c}\mathrm{T}_{6}: \text { DOS } 20 \text { July }+ \text { N90kg ha } \\
\mathrm{k}^{-1}, \mathrm{~kg} \mathrm{ha}^{-1}\end{array}$ & 15.66 & 140.30 & 189.40 & 143.23 & 1.66 & 373.36 & 72.26 \\
\hline 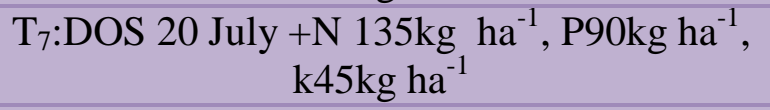 & 26.00 & 143.53 & 195.26 & 151.30 & 1.83 & 390.56 & 78.23 \\
\hline $\mathrm{T}_{8}$ : DOS 30 July + control nutrients & 22.33 & 109.86 & 144.96 & 114.66 & 1.00 & 308.16 & 54.40 \\
\hline 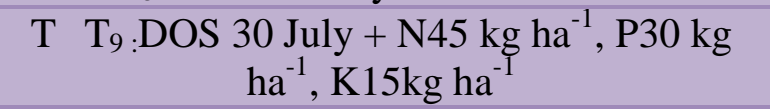 & 30.66 & 126.90 & 175.16 & 122.53 & 1.16 & 325.20 & 60.53 \\
\hline $\begin{array}{c}\text { T10:DOS } 30 \text { July +N90kg ha-1, P60kg } \\
\text { ha }^{-1}, \mathrm{k}^{-10 \mathrm{~kg} \mathrm{ha}^{-1}}\end{array}$ & 20.00 & 136.40 & 185.60 & 136.23 & 1.50 & 349.66 & 66.06 \\
\hline $\begin{array}{c}\mathrm{T}_{11} \text { :DOS } 30 \text { July }+\mathrm{N} 135 \mathrm{~kg} \mathrm{ha}^{-1}, \mathrm{P} 90 \mathrm{~kg} \mathrm{ha}^{-1}, \\
\mathrm{~K} 45 \mathrm{~kg} \mathrm{ha}^{-1}\end{array}$ & 24.00 & 144.56 & 190.10 & 143.93 & 1.50 & 381.00 & 70.23 \\
\hline F- test & NS & NS & & $\mathrm{S}$ & NS & $\mathrm{S}$ & $\mathrm{S}$ \\
\hline S. Em $( \pm)$ & 5.31 & 3.41 & & 0.73 & 0.14 & 1.11 & 0.34 \\
\hline C. D. at $5 \%$ & - & - & 1.28 & & & 3.25 & 1.03 \\
\hline
\end{tabular}


Table.2 Effect of different levels of nutrient and date of sowing on growing degree day GDD ( $\mathrm{C}$ day) at flowering and tasseling stage of maize

\begin{tabular}{|c|c|c|}
\hline Treatment combinations & $\begin{array}{l}\text { GDD ( C day) at } \\
\text { flowering stage }\end{array}$ & $\begin{array}{l}\text { GDD ( C day) at } \\
\text { tasseling stage }\end{array}$ \\
\hline$T_{0}$ : DOS 10 July + Control Nutrients & 803.66 & 1243.66 \\
\hline$T_{1}$ : DOS 10 July +N45kg ha ${ }^{-1}$, P $30 \mathrm{~kg} \mathrm{ha}^{-1}, \mathrm{k15} \mathrm{kg} \mathrm{ha}^{-1}$ & 826.00 & 1206.66 \\
\hline $\mathrm{T}_{2}:$ DOS 10 July + N 90kg ha ${ }^{-1}$, P60kg ha ${ }^{-1}, \mathrm{k30kg} \mathrm{ha}^{-1}$ & 855.00 & 1162.33 \\
\hline $\mathrm{T}_{3}:$ DOS 10 July +N135kg ha-1, P 90kg ha ${ }^{-1}, \mathrm{k}^{-15} \mathrm{~kg} \mathrm{ha}^{-1}$ & 871.66 & 1121.66 \\
\hline$T_{4}:$ DOS 20 July + control nutrients & 810.33 & 1301.66 \\
\hline$T_{5:}$ DOS 20 July + N45 kg ha ${ }^{-1}, P 30 \mathrm{~kg} \mathrm{ha}^{-1}, \mathrm{~K} 15 \mathrm{~kg} \mathrm{ha}^{-1}$ & 843.66 & 1283.33 \\
\hline$T_{6}:$ DOS 20 July +N 90kg ha ${ }^{-1}$, P60kg ha ${ }^{-1}, \mathrm{k30kg} \mathrm{ha}^{-1}$ & 885.00 & 1232.66 \\
\hline $\mathrm{T}_{7}$ : DOS 20 July +N 135kg ha ${ }^{-1}$, P90kg ha ${ }^{-1}, \mathrm{k}^{2} \mathrm{~kg} \mathrm{ha}^{-1}$ & 904.00 & 1163.00 \\
\hline $\mathrm{T}_{8}$ : DOS 30 July + control nutrients & 830.00 & 1366.33 \\
\hline $\mathrm{T}_{9}:$ DOS 30 July + N45 kg ha ${ }^{-1}, P 30 \mathrm{~kg}$ ha ha $^{-1}, \mathrm{~K}_{15} \mathrm{~kg} \mathrm{ha}^{-1}$ & 879.66 & 1347.00 \\
\hline $\mathrm{T}_{10:}$ DOS 30 July +N90kg ha ${ }^{-1}$, P60kg ha ${ }^{-1}, \mathrm{k30kg} \mathrm{ha}^{-1}$ & 903.66 & 1306.00 \\
\hline$T_{11:}$ DOS 30 July +N135kg ha ${ }^{-1}$, P90kg ha ${ }^{-1}, K_{45} k$ ha $^{-1}$ & 933.66 & 1225.00 \\
\hline F- test & NS & $\mathrm{S}$ \\
\hline S. $\operatorname{Em}( \pm)$ & 5.35 & 0.78 \\
\hline C. D. at $5 \%$ & & 2.35 \\
\hline
\end{tabular}


Table.3 Effect of different levels of nutrients and dates of sowing on heat use efficiency at 75 DAS (Dry matter basis)

\begin{tabular}{|c|c|c|c|c|c|}
\hline \multirow{2}{*}{ Levels of SD } & \multicolumn{3}{|c|}{ At 75 DAS } & \multirow{2}{*}{ Mean } \\
\cline { 2 - 6 } & \multicolumn{3}{|c|}{ Level of Nutrients } & $\mathrm{Nu}_{3}$ & \\
\cline { 2 - 5 } & $\mathrm{Nu}_{0}$ & $\mathrm{Nu}_{1}$ & $\mathrm{Nu}_{2}$ & 9.99 & 8.85 \\
\hline $\mathbf{D}_{\mathbf{1}} \mathbf{1 0}$ july & 7.37 & 8.66 & 9.38 & 10.38 & 9.11 \\
\hline $\mathbf{D}_{\mathbf{2}} \mathbf{2 0}$ july & 7.68 & 8.87 & 9.54 & 9.92 & 8.91 \\
\hline $\mathbf{D}_{\mathbf{3}} \mathbf{3 0}$ july & 7.90 & 8.45 & 9.39 & 10.09 & \\
\hline Mean & 7.65 & 8.66 & 9.43 & & C.D. at 5\% \\
\hline & & $\mathrm{F}-$ test & $\mathrm{S} . \mathrm{Em} .( \pm)$ & & 0.13 \\
\hline Due to DS & & $\mathrm{S}$ & 0.04 & & 0.15 \\
\hline Due to nutrients & & $\mathrm{S}$ & 0.05 & & 0.27 \\
\hline Inter (DxNu) & & $\mathrm{S}$ & 0.09 & & \\
\hline
\end{tabular}

Table.4 Interaction table on effect of different levels of Nutrients and sowing date on the yield and yield attributes of Maize (Zea mays L.)

\begin{tabular}{|c|c|c|c|c|}
\hline Treatment combinations & Grain yield $\left(q\right.$ ha $\left.^{-1}\right)$ & Stover yield $\left(\mathrm{q} \mathrm{ha}^{-1}\right)$ & Harvest index (\%) & Test weight (g) \\
\hline$T_{0}$ : DOS 10 July + Control Nutrients & 30.00 & 69.33 & 30.21 & 174.33 \\
\hline$T_{1}: D O S 10$ July +N45kg ha ${ }^{-1}, P 30 \mathrm{~kg} \mathrm{ha}^{-1}, \mathrm{k15} \mathrm{kg} \mathrm{ha}^{-1}$ & 38.66 & 78.00 & 33.12 & 191.66 \\
\hline $\mathrm{T}_{2}:$ DOS $10 \mathrm{July}+\mathrm{N} 90 \mathrm{~kg} \mathrm{ha}^{-1}$, P60kg ha ${ }^{-1}, \mathrm{k} 30 \mathrm{~kg} \mathrm{ha}^{-1}$ & 43.33 & 81.66 & 34.66 & 204.33 \\
\hline $\mathrm{T}_{3}:$ DOS $10 \mathrm{July}+\mathrm{N} 135 \mathrm{~kg} \mathrm{ha}^{-1}, \mathrm{P} 90 \mathrm{~kg} \mathrm{ha}^{-1}, \mathrm{k} 45 \mathrm{~kg} \mathrm{ha}^{-1}$ & 57.33 & 88.66 & 39.26 & 222.00 \\
\hline $\mathrm{T}_{4}:$ DOS 20 July + control nutrients & 27.64 & 67.26 & 29.12 & 170.62 \\
\hline$T_{5:}$ DOS 20July+ N45 $\mathrm{kg} \mathrm{ha}^{-1}$, P $30 \mathrm{~kg} \mathrm{ha}^{-1} \mathrm{~K} 15 \mathrm{~kg} \mathrm{ha}^{-1}$ & 35.75 & 74.44 & 32.44 & 188.40 \\
\hline$T_{6}:$ DOS 20 July +N 90kg ha ${ }^{-1}$, P60kg ha ${ }^{-1}$, k30kg ha $^{-1}$ & 42.43 & 79.48 & 34.80 & 198.47 \\
\hline $\mathrm{T}_{7}:$ DOS 20 July +N 135kg ha ${ }^{-1}$, P90kg ha ${ }^{-1}, \mathrm{k}^{2} \mathrm{~kg} \mathrm{ha}^{-1}$ & 54.87 & 85.40 & 39.10 & 210.66 \\
\hline$T_{8}:$ DOS 30 July + control nutrients & 25.36 & 63.23 & 28.62 & 158.20 \\
\hline$T_{9}$ :DOS 30 July+N45 kg ha ${ }^{-1}$, P $30 \mathrm{~kg}$ ha $^{-1}$, K $15 \mathrm{~kg} \mathrm{ha}^{-1}$ & 31.62 & 70.33 & 31.03 & 165.23 \\
\hline 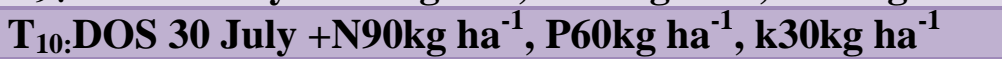 & 42.09 & 75.29 & 3585 & 172.20 \\
\hline 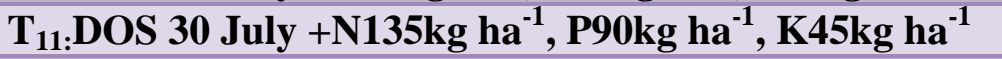 & 49.92 & 79.33 & 38.63 & 190.64 \\
\hline F- test & S & S & $\mathrm{S}$ & $\mathrm{S}$ \\
\hline S. Em $( \pm)$ & 0.34 & 0.38 & 0.02 & 0.48 \\
\hline C. D. at $5 \%$ & 1.03 & 1.18 & 0.07 & 1.46 \\
\hline
\end{tabular}


The interaction effect of different levels of nutrients and dates of sowing on HUE was also found significant, the maximum HUE $10.38 \mathrm{~kg} \mathrm{ha}^{-10} \mathrm{C}^{-1}$ day $^{-1}$ was found in treatment combination $\mathrm{D}_{2}+\mathrm{Nu}_{3}$ and minimum $7.37 \mathrm{~kg}$ ha ${ }^{-1}{ }^{0} \mathrm{C}^{-1}$ day ${ }^{-1}$ was recorded in $\mathrm{D}_{1}+\mathrm{Nu}_{0}$ and critical difference at $5 \%$ level of significance of interaction was recorded 0.27 .

similar result also have been recorded by Leelarani et al., (2013) is that HUE decreases with delay sowing of maize crop and nutrient levels has significant effect on HUE.

The result of the experiment are concluded as the maximum plant height plant $^{-1}$, number of cob plant ${ }^{-1}$, cob girth plant ${ }^{-1}$, cob length plant $^{-1}$, number of grains $\mathrm{cob}^{-1}$, grain yield $\mathrm{cob}^{-1}$, grain yield $\mathrm{q} \mathrm{ha} \mathrm{h}^{-1}$, stover yield $\mathrm{q} \mathrm{ha}{ }^{-1}$, biological yield $\mathrm{q} \mathrm{ha}^{-1}$ was found in the treatment combination $\mathrm{T}_{3}, 150 \%$ of R.D.F (nitrogen $135 \mathrm{~kg} \mathrm{ha}^{-1}$, phosphorus $90 \mathrm{~kg} \mathrm{ha}^{-1}$, potash $45 \mathrm{~kg} \mathrm{ha}^{-1}$ and $10^{\text {th }}$ July Sowing date).

The minimum GDD at maturity of crop $1596.00{ }^{0} \mathrm{C}$ was found in treatment $\mathrm{T}_{3}, 150 \%$ of R.D.F (nitrogen $135 \mathrm{~kg} \mathrm{ha}^{-1}$, phosphorus 90 $\mathrm{kg} \mathrm{ha}^{-1}$, potash $45 \mathrm{~kg} \mathrm{ha}^{-1}$ and $10^{\text {th }}$ July Sowing date) and minimum in $\mathrm{D}_{1}\left(10^{\text {th }}\right.$ July sowing date) was $1672.75{ }^{0} \mathrm{C}$. The minimum heat use efficiency $8.85 \mathrm{~kg} \mathrm{ha}^{-1} \mathrm{C}^{-1}$ day $^{-1}$ was found in $\mathrm{D}_{1}\left(10^{\text {th }}\right.$ July sowing date $)$ and minimum 7.37 $\mathrm{kg} \mathrm{ha}^{-1}{ }^{0} \mathrm{C}^{-1}$ day $^{-1}$ in treatment combination $\mathrm{T}_{0}$ $\left(10^{\text {th }}\right.$ July sowing date + Control NPK).

Help our farmer to apply balanced fertilizer application and suitable sowing time which will be synchronized with crop demand and also will reduce the cost of production.

\section{References}

Awasthi, U.D., Kumar, K., Singh, M.and Kumar, S. (2009). Performance of maize varieties under varying dates of sowing in prevailing agro- climatic condition of central Uttar Pradesh. Indian Journal of Sciences, 79: pp. 385-387.

Critchfield, H.J. 2009. General climatology (Fourth edition). Prentice -Hall of India private Limited, New Delhi.

Hara, A. (2003). Performance of maize hybrids in relation to planting dates and nitrogen level. M.Sc. Thesis, Punjab Agricultural University, Ludhiana.

Kara, B. (2011). Fresh ear yield and growing degree days of sweet corn in different sowing dates in south western Antolia Region. Turkish Journal of Field Crops, 16(2): pp. 166-171.

Kumar, P., Halepyatia, S., Pujari B.T. and Desai, B.K. (2007) Effect of Integrated Nutrient Management on Productivity, Nutrient Uptake and Economics of Maize (Zea mays L.) Under Rainfed Condition Karnataka J. Agric. Sci., 20(3): pp. 462-465.

Kumar, A. (2009). Production potential and nitrogen use efficiency of sweet corn (Zea mays L.) influenced by different planting density and nitrogen levels. Indian Journal of Agriculture and Sciences 79: 351-355.

Leelarani, P., Sreenivas, G. and Rajireddy D. (2013). Evaluating contribution of weather to growth and yield of khrif maize under irrigated conditions. Journal of Agrometeorlogy, Hydrabad, 15(2): pp. 156-158.

Parashar, A. (2011). Phenology \& productivity of maize cultivars as influenced by crop weather environment. M.Sc. Thesis, Maharana Pratap University of Agriculture and Technology,

Rafiq, M.A., Malik M.A. and Hussain, M. 2010. Effect of fertilizer levels and plant densities on yield and protein content of maize. Pakistan Journal of Agricultural Science, 47: 201-208.

Rao, G.G.S.N. Rao, Kesava Rao, A.V.R., 
Ramakrishna, Y.S. and Victor, W.S. Sowunmi, F.A. and Kintola, J.O.A. 2010. 1999. Resources characterization of Dry lands: Climate in a book, Fifty years of Dry land Agricultural Research in India (Eds. H.P. Singh et al.,) CRIDA, Hyderabad. Effect of climatic variability on maize production in Nigeria. Research Journal of Environment. and Earth Science, 2(1): 19-30.

\section{How to cite this article:}

Shalu Shyoran, Ram Bharose and Rajveer. 2019. Effect of Different Levels of Nutrients and Dates of Sowing on Growth and Yield of Maize Crop (Zea mays L.). Int.J.Curr.Microbiol.App.Sci. 8(12): 1530-1538. doi: https://doi.org/10.20546/ijcmas.2019.812.183 